Also? Der alte fruchtlose Streit eines 'Entweder/Oder ist, wie schon Schumpeter in Zusammenhang mit der Menger/Schmoller-Auseinandersetzung sagte, »im Wesentlichen eine Geschichte vergeudeter Energie«(Schumpeter 1965: 994). Die Fragen bezüglich Pluralismus, Mainstream-Ansprüchen und dergleichen bleiben aktuell und Gegenstand fortlaufender Diskussionen. Die FAZ/HB-Konfrontation hat allerdings wenig dazu beigetragen.

\title{
Literatur
}

Feyerabend, P. (1976): Wider den Methodenzwang, Frankfurt/Main.

Marshall, A. (1920/1994): Principles of Economics, $8^{\text {th }}$ Edition, London: Macmillan.

Schumpeter, J.A. (1965): Geschichte der ökonomischen Analyse, Göttingen.

\section{Assessing economic research and the future of heterodox economics. Failures and alternatives of journals, departments, and scholars rankings Wolfram Elsner ${ }^{*}$ Fred Lee}

\section{Journal and department rankings and the ruling game of mainstream economics}

Evaluating economic research today is a most contested field. This applies, most notably, since individual careers of a whole generation of critical young economists are affected. And it applies in economics, perhaps more than in any other discipline, since it is the most important academic discipline for the ideological legitimization of capitalism and one of the few, perhaps the only, fundamentally divided and contested discipline. What the ruling forces of the economy, of professional politics, of science administration, and particularly of economic science have made out of the complex issues and processes of evaluating research quality is reducing them down to a simplistic, allegedly exact, objective, and obvious, but fundamentally mistaken procedure of a one-dimensional ranking of quantitative domination, a cumulative dictatorship of mass. And this is done in surprisingly unprofessional ways, subject to many obvious misconceptions and failures. For example, the

* Professor of Economics, University of Bremen, Faculty of Business Studies and Economics, iino Institute for Institutional and Innovation Economics.

** Professor of Economics, Department of Economics, University of Missouri at Kansas City.

(C) INTERVENTION 7 (I), 20IO, 3I-4I 
International Mathematical Union, the International Council of Industrial and Applied Mathematics, and the Institute of Mathematical Statistics have argued in a joint report released in June 2008 that "the belief that citation statistics are accurate measures of scholarly performance is unfounded", the »use of such statistics is often highly subjective», »the validity of these statistics [...] is neither well understood nor well studied «, and »that sole reliance on citation data provides at best an incomplete and often shallow understanding of research «. In the same vein, economist Bruno Frey found "that such rankings do not effectively measure research quality «, and »career decisions based on rankings are dominated by chance« (Frey/Rost 2008).

Not surprisingly, in economics, the problems are quite obvious. Economics is a deeply divided science dominated by mainstream or neoclassical economics. In spite of its dominance, it is not above criticism. Physicist Marc Buchanan argues that it is the only scientific discipline that still is not modern, since its mainstream is not complex but simplistic with its dominant market-optimality and equilibrium vision (as argued in the New York Times in October 2008; see Buchanan 2008). Moreover, this outmoded mainstream has to be considered responsible - as far as science can be responsible - for the biggest and deepest global financial, economic, food and resources, climate, social, political and moral crises and catastrophes. As even the London Times has stated in February 2009:

"Economists are the forgotten guilty men. Academics - and their mad theories are to blame for the financial crisis. They too deserve to be hauled into the dock" (Kaletsky 2009a).

Similarly, the Financial Times had a lengthy article about the "uselessness of most state of the art academic monetary economics« in March 2009 (Buiter 2009). Countless other critical declarations of economists have come out since the burst of the giant financial bubble. One shall just be mentioned: David Colander, Hans Foellmer, Alan Kirman and other wellknown complexity and evolutionary economists have launched the so called Dahlem-Report in February 2009, 'The Financial Crisis and the Systemic Failure of Academic Economics.

Despite these severe and fundamental failures, over the last three decades the ruling forces of mainstream economics and their allies in politics, public administration and in the organizations of big business utilize rankings as a power device to rule, to direct research funds to their own ranks, to make or destroy careers of critical economists, to up- and downgrade journals and departments, and, particularly, to elbow out of academic research, teaching, and advice their potential competitors of the diverse heterodox approaches (Lee/Elsner 2008, Lee 2009, Butler 20I0, Katzner 20I0).

The dramatic and aggravating real-world problems require an opening up of the neoliberal mythologies which are based on the simplistic core model of the soptimal, equilibrating and stable market economy`. A new, broad reflection of the practices of mainstream economics and a motion towards an active pluralism in all leading departments, schools, and journals appears to be overdue in face of the severest crisis the capitalist market economy has experienced since the I930s. 
However, on the contrary, it appears that, building on its long running current attack, there is a new offensive of the mainstream alliance against the heterodox economists to push them out of academia completely. In fact, after some few months of confusion and uncertainty about the disaster caused by their creeds, orders, and advice, mainstream economists are back again developing their own particular narratives of the crisis (Taylor 2009, Meltzer 2009). They argue that it was caused by too much - and inherently deficient - state intervention rather than too little regulation and surveillance in the public interest. After some months of shock and relative retreat and quietness it also remains obvious that neoliberal economists still are in power - and some even have newly come into power in the Obama administration - and are back with smore market, against real financial market or health insurance reforms, but with hundreds of billions of taxpayer money put into the balances of the gamblers' and desperadoes' banks, funds and insurance companies.

And this seems to be exactly what the leading elites require in times of crises: banning real change, persecuting critics in the economics profession who want the chance to organize real change in order to realign individual business behavior with the collective requirements of the public. Thus, it seems that the very economic crisis and depression becomes an additional cause for ideological cleansing rather than a critical self-reflection and change (for a recent case, see the closing down of the pluralist economics department at the University of Notre Dame).

In her Shock-Doctrine book Naomi Klein (Klein 2007) has developed and substantiated the idea that the ruling forces in fact are not interested in instrumental problem-solving. Others, such as Marc Lutz, have analyzed economics as the still Dismal Science that today would accept, if not promote, insecurity, anxiety, turbulence, and pauperization to keep the ruling castes in power and serve their interests (Lutz 2008).

When we did the introduction of a special issue of On the Horizon in 2008, we disagreed with some critical economists like S. Dow, J. Davis, T. Lawson, R. Backhouse, and $\mathrm{D}$. Colander who suggested that there is and will be more pluralism emerging in economics and that the mainstream somehow is fragmenting and dissolving (as cited in Lee/Elsner 2008). Our pessimistic view of an ongoing counterattack, in contrast, was based on the fact that even a relative dominance of heterodoxy in terms of research questions, approaches, and methodologies over the last, say, 25 years would have not spilled over into the areas of funding and recruitment for heterodox economists, of the curricula of mass teaching and the advice business, and would leave untouched the mainstream's and its allies' general world view.

Their individual human capital and their vested interests continue to dominate the economics profession through their control of the peer review process and the ranking of economic journals and departments, and to dominate over economic and societal problem solving. As noted above, the core of the neoclassical paradigm and neoliberal world view remains unshaken - despite the financial market crisis and the fact that financial markets have been flooded with taxpayers' billions. It is of little help that even some prominent economists warn against the destruction of motivations of many young economists and against the obvious "undesired lock-in effects« of the ruling ranking game (Frey/Osterloh 2006). 
The »Ivory Tower [remains] Unswayed by Crashing Economy«, as Patricia Cohen has said in the New York Times in March 2009, stating that "The basic curriculum will not change."

This applies despite both a currently increasing academic attractiveness of research and publicity for heterodox themes, perspectives, and persons in some print and internet media. See, for instance, the articles on Hip Heterodoxy in The Nation in June 2007 (Hayes 2007), the celebration of the brave army of heretics in economicprincipals.com in May 2008 (Warsh 2008) or the New York Times determining "a growing will to debate fundamental assumptions in Econ Departments« in July 2007 (Cohen 2007). The latter is probably not going to happen.

\section{Peer reviewing and mainstream journal' qualities}

Although - or because of - peer reviewing is essential for stabilizing mainstream economics and the reproduction of mainstream economists in academia, the practices of the ruling peer review process have been under attack for some time. Chubin and Hackett in their book Peerless Science (1990) already had reported

"that only $8 \%$ of the members of the Scientific Research Society agreed that peer reviews work well as it is" (Chubin/Hackett 1990: 192).

Peer reviewing has come under scrutiny even by the EU Science Foundation - ESF - that had held a conference on peer reviews already in October 2006 (ESF 2006). B. Frey has a much cited paper on Publishing as Prostitution (2002: 2) where he stated that authors have to "slavishly follow the demands of anonymous referees without property rights on the journals they advise», that is, without being committed to the journal and its publication process - or the individual careers of the submitters - let alone to the knowledge impact of the whole procedure. In fact, there are many case studies out that, for instance, have ascertained that "peer review lacks validity, impartiality, and fairness" (Seidl et al. 2005: 506).

In another study, it has been found that the top journals exert a strong institutional and regional `favoritism ‘ and have further selection biases (Cherkashin et al. 2008). Furthermore, it has been demonstrated that there are straightforward path-dependent effects - or herd behavior one might say - in the citation culture: Often cited papers and authors are cited more often, that is, the fame of papers and authors, once gained, has lasting increasing returns to scale (see, e.g., Tol 2007).

A. Oswald (University of Warwick) has found, in the run-up to the British Research and Assessment Exercise (RAE) 2008, that "The publication system is full of error «. It routinely would put low-quality papers into the top-ranked journals (Oswald 2006). He stated that

»Unless hiring committees, promotion boards and funding bodies are aware of this fact, they are likely to make bad choices about whom to promote and how to allocate resources." 
Similarly, Frey has stated a P Publication Impossibly Theorem : the publication incentive structure in favor of the stop < journals (with their few paper slots) is such that the wrong output may be produced in an inefficient way and wrong people may be selected (Frey 2009).

\section{Alternatives to the ruling game: Pluralism and diverse methodologies}

Finally and concretely, many have shown that citation impacts differ considerably across the different bibliographic electronic sources, such as Econlit, JSTOR, Scopus, and Google Scholar, with major impacts particularly on the ranking positions of heterodox journals and scholars (for example, D'Orlando 20Io). This implies that heterodox themes, fields, and authors do vary drastically in attention and rankings, depending on the data bases of the different rankings.

Hence, time seems to be more than ripe for pluralism in economics (for pluralist teaching, see Raveaud 2008), as the London Times has put it in February 2009: "Now is the time for a revolution in economic thought" (Kalestky 2009b). This would have to be a move towards a culture of active pluralism. It implies looking at alternative, senlightened methodologies of evaluating scholarship that do not discriminate but include and appreciate any qualified contribution to the growth of the social knowledge fund.

Preparing the ground for this culture was the aim of a workshop on 'Assessing economic research in a European context: The future of heterodox economics and its research in a non-pluralist mainstream environment, held at the University of Bremen on 26-27 June 2009 and organized by the authors of this report. Marcella Corsi, Carlo D'Ippoliti, Frederico Lucidi, Alan Freeman, Dieter Boegenhold, Agnieszka Ziomek, Fred Lee, Jakob Kapeller, Marco Novarese, Andrea Pozzali, Bernard Vallageas, and Harry Bloch dealt with this in their contributions to this workshop.

Marcella Corsi, Carlo D'Ippoliti and Frederico Lucidi (University of Rome, Roma I, La Sapienza) presented case studies of the research evaluation procedure in Italy. They examined the research evaluation recently undertaken in Italy. They argued that by predicating the quality of publications on a "value scale shared by the international scientific community", publications in mainstream journals are favored and departments/universities will continue to discriminate in favor of publications in mainstream journals. To get around this tyranny of peer evaluation, they proposed a theory-neutral quantitative indicator for research quality. Dieter Boegenhold (University of Bolzano) discussed the methodological and institutional context of heterodox economics and its relationship to mainstream economics, and Agnieszka Ziomek (University of Poznan) dealt with the emergence of heterodox economics in Poland since 1989. Of particular interest was her discussion of how the ending of the transition period in the late I990s provided a first little space for heterodox economics to emerge. That is, since 2000, problems of employment, local and regional development, and clientelism have pushed some Polish economists to look for ideas and arguments outside of mainstream economics to deal with them. Alan Freeman (University of Greenwich) argued in his paper that academic economics in the United Kingdom is in a state of regulatory capture by mainstream economists. As a result, there is an enforcement of one way of 
thinking about economic problems which has resulted in the economics profession being unable to anticipate and understand the financial crash and recession of 2008 . To alter this, a benchmarking for pluralism in economics is needed which he developed.

Box I: Connected critical activities

Most will remember the famous Plea for a Pluralistic and Rigorous Economics published in the American Economic Review in 1992, initiated by D. McCloskey, G. Hodgson and U. Maki and signed by 44 well-known economists, among them W.B. Arthur, M. Blaug, K. Boulding, P.A. Davidson, J.K. Galbraith, N. Georgescu-Roegen, R. Goodwin, R. Heilbroner, H. Minsky, R.R. Nelson, F. Modigliani, L. Pasinetti, K. Rothschild, P.A. Samuelson and H. Simon. In this tradition, there have been many more specific activities of that kind in the recent years:

- Italian economists have launched an open letter against the current practices of science evaluation in 2009. Among them are G. Becattini, P. Garegnani and L. Pasinetti (see Lettera aperta 2009).

- $\quad$ French scholars have launched different public declarations and petitions, among them one against the French and EU practices of journal rankings, signed by more than 90 French social science journals' editors (see La defense des revues 2009).

- In a declaration, more than 35 journals from the history of science and technology field of July 2008, printed in a joint editorial, declare their dissent with the practice of the European Reference Index for the Humanities (ERIH), developed by the ESF. They explain their "refusal to allow our field to be managed and appraised in this fashion" and "have asked the compilers of the ERIH to remove our journals' titles from their lists« (see Journals under threat 2008).

- Among others, the French also have developed, and use, a different ranking list of economic journals wherein, for instance, the (more or less) heterodox journals Cambridge Journal of Economics, Economy and Society, Industrial and Corporate Change, Journal of Economic Methodology, Journal of Economic Perspectives, Research Policy and Journal of Evolutionary Economics are rated A, and Journal of Economic Issues, Journal of Post Keynesian Economics, Review of Social Economy, Review of Radical Political Economy and Socio-Economic Review are B, the Review of Political Economy, Journal of Socio-Economics and International Review of Applied Economics are C. They all are either ranked lowly or not at all in the official rankings.

- Also, the Economic Society of Australia has, on the basis of a poll of all full professors of economics in the country, constructed and submitted an alternative ranking list. Here the following heterodox journals occur with A rankings: Cambridge Journal of Economics, Journal of Economic Issues, Journal of Evolutionary Economics, Journal of Post Keynesian Economics, Economy and Society, Review of Black Political Economy, Review of International Political Economy. 
- Many departments have developed their own ranking lists to evaluate their members' research records. La Trobe University (Sidney, AUS), for instance, lists the following heterodox journals top (`Band A $)$ : Cambridge Journal of Economics, European Journal of the History of Economic Thought, Feminist Economics, History of Political Economy, Journal of Economic Perspectives, Journal of the History of Economic Thought; and 'Band B journals are: Applied Economics, Applied Economic Letters, Economy and Society, International Review of Applied Economics, Journal of Economic Issues, Journal of Economic Methodology, Journal of Evolutionary Economics, Journal of Post Keynesian Economics, Review of Political Economy, among others. Elgar, Routledge, and University of Michigan Press are listed among the top publishers.

- It is said, that there exist around 80 different ranking lists on national and department bases.

We also have to address the different subject areas that specialized journals are in, that is, different clusters of journals, and both the `big mountain of the general mainstream journals and the smaller mountains of specialist and heterodox journals. We might make progress here with statistical cluster or factor analyses. In addition, within the smaller clusters, the relative cross-citation intensity might easily be as high as among the top mainstream journals. Statistically, however, one thing would be disturbing: the heterodox journals cite the mainstream journals, but the mainstream journals do not cite the heterodox ones - this is what a paper by Fred Lee addressed in the workshop. If we look at the different subject areas, we find that specialized rankings of journals and departments may considerably deviate from the sbig overall stotal-mass` rankings (see also already Grijalva/Nowell 2008, in their exercise on rankings by field of expertise). A paper by Fred Lee (University of Missouri-Kansas City) and Therese Grijalva and Clifford Nowell (Weber State University) explored the impact that a more equitable quality weighting for heterodox economic journals would have on the ranking of American economics departments with doctoral programs. In particular, a new quality weighting for heterodox journals in the Social Science Citation Index (SSCI) combined with including six heterodox journals not included in the SSCI, resulted in a significant movement of departments with a heterodox presence, and depending on the ranking criteria some pluralist departments actually move into the top thirty departments. The significance of the paper is that a small change in the evaluation of heterodox research makes a relatively big difference in department ranking.

In a further paper Fred Lee dealt with the ranking of heterodox journals in terms of research quality and the ranking of heterodox journals in terms of pluralism. He broached a quality-equality ranking of heterodox and mainstream journals in terms of research quality. The paper was largely devoted to explaining the methodology for each of the rankings and some ranking evidence was given to illustrate the methodology. One implication of the paper was the issue of whether it would be better to group journals in particular categories instead of ranking them. 
In his paper, Jakob Kapeller (University of Linz) discussed in great detail the inadequacies of the impact factor in general and also with regard to heterodox economics. He then outlined various options that heterodox economists could take to escape the clutches of the impact factor. Kapeller noted that heterodox economists cite mainstream journals whereas the reverse is not true, which means that heterodox economists inflate the impact factors for mainstream journals - which in turn are used to argue how superior in terms of quality mainstream journals are relative to heterodox journals.

Furthermore, addressing the specialisation suggests looking at the whole, structured, multifaceted `landscape of journals and departments and their interrelations, their division of labor and cooperation. Fred Lee has suggested for long to develop the diversity of citations - i.e., of different cited sources - as an independent factor and criterion of journal evaluation. In the same vein, we should look at the diversity and the pluralism of departments. Similarly, although rather general, Frey and Osterloh (2006) have suggested to replace rankings and research evaluation by some input quality` control and 'process` control. This seems to make a more cooperative, networking or contribution-to-the-knowledge-fund perspective feasible, rather than a simplistic competitive, ,conspicuous, and semulativer ranking view. How much does a journal really contribute to societal knowledge creation and diffusion?

The internet facilities provide new horizons of both publication and quality determination through true citations over all. So what will a new balance be among printed journals, book publishers, and online texts? We can freely post and diffuse research papers nowadays on the net, also using well-established channels and platforms there. What does this all imply for the role of the scientist in society, for quality evaluation, for pluralism, and last not least for heterodox convergence? Marco Novarese's and Andrea Pozzali's, Bernard Vallageas', and again Freeman's as well as others' papers have addressed this at the Bremen workshop. Marco Novarese (University of Piemonte Orientale) and Andrea Pozzali (University of Milan) presented a paper on what it means to be a good economist under current technological and societal conditions. They advanced the question whether academic economics is useful to society and hence deserve to be supported by the state - and the society at large. However, the incentive structure of mainstream economics favors publications in a set of inward looking journals and punishes those economists that do not follow it. This has led to an intellectual stifling of pluralist intellectual debate within the profession and of the ability to contribute to the wider social discussion of important economic issues. This suggests that a new social contract is needed for economics. Bernard Vallageas (University of Paris-Sud) gave a paper that advanced a similar argument with particular application to the academic situation in France.

Finally, we will have to look at countries and their specific conditions, namely their different compositions of the discipline in terms of departments, journals, and scholars. There have been some country case study papers in the workshop on Italy (Corsi, D'Ippoliti, and Lucidi), Poland (Ziomek), already dealt with above, and one on Australia by Harry Bloch (Curtin University of Technology). He discussed the move by the Australian government towards its first national research evaluation exercise. One component of the exercise is to develop research classifications for research in economics; and he showed that this could 
be hazardous to the research health of heterodox economists. Bloch also discussed the current controversy over the ranking of journals which will be used to rank departments and indicated the possible impact for heterodox economics. Lastly, he suggested that when the final construction and uses of the evaluation metrics commences, heterodox economists will face still additional problems. He made clear that like in the case of Italy - and Spain and the United Kingdom for that matter - the evaluation exercise will be used by mainstream economists to cleanse Australian economics of heterodox economists.

Various papers in the workshop dealt with the bibliometric techniques in detail -impact factors, different types of citation-based rankings, and importance of working with both bibliometric and peer-evaluation approaches. In this context, citation data were presented showing that heterodox journals individually and as a group import more citations from mainstream journals than they import from heterodox journals by a factor of more than two; and the balance of citation trade between mainstream and heterodox journals is on the order of twenty-five times greater in favor of mainstream journals. Essentially, it appears that in terms of citations, heterodox economists talk with mainstream economists more than they talk with each other.

In response, such results suggest the following strategic and behavioral considerations for heterodox economists:

- establish the idea that economics is a contested discipline which means that a single bibliometric measure for research quality such as the impact factor - is inappropriate;

- better metrics based on different evaluative criteria be developed for evaluation research and ranking journals and departments; the better metrics would include alternatives to the flawed impact factor and the use of peer-evaluation; and promote the better metrics in other disciplines as a way to establish their usefulness;

- allow for a wider dissemination of heterodox papers - pre- and post-print - and via all available digital channels as a way to increase their citations;

- promote the view that heterodox economists should talk to each other as well, if not more, than they talk to mainstream economists - in terms of citation counts - that heterodox associations should engage in more co-operative activities so to increase a dense social network between their members; that editors of heterodox journals have a responsibility to promote this change of emphasis of conversation; and that editors of heterodox journals should work co-operatively with each other to promote the development of a more dense network of citations between their journals;

- encourage heterodox journals currently not included in the SSCI to meet the Thomson Reuters journal selection criteria and apply to join it;

- activities for promoting pluralism as a benchmark in economics: lobby for a pluralistic clause within the 8th - and following - Research Framework Program of the European Union; talk to national and EU funding bodies, policymakers, trade unions, and the media; develop a code of conduct for economists; and promote a public inquiry into economics; 
- develop an economics resource website that enlightens about ranking studies and lists.

As follow-ups to the Bremen Ranking Workshop, special sessions on these issues occurred at the conferences of the Research Network on Macroeconomics and Macroeconomic Policies, in Berlin, October 2009, of the European Association of Evolutionary Political Economy (EAEPE) in Amsterdam in November 2009, and of the Union for Radical Political Economy (URPE) at the ASSA Meetings in Atlanta in January 2010 (2 sessions).

The revised papers of the Bremen Workshop, together with some additional papers that have been elaborated in this context after the workshop (by Bruce Cronin, University of Greenwich and Martha Starr, American University) will be published in a special issue (edited by Fred Lee and Wolfram Elsner) of the American Journal of Economics and Sociology and as a hardcover issue.

\section{References}

A plea for a pluralistic and rigorous economics (1992), in: American Economic Review, 82, May. Buchanan, M. (2008): This economy does not compute, in: The New York Times, OP-ED, October I, 2008.

Buiter, W. (2009): The unfortunate uselessness of most 'state of the art academic monetary economics, in: The Financial Times, March 3, 2009.

Butler, G. (20I0): The Sydney Insurrection. The Battle for Economics at the University of Sydney, in: Challenge, $53(2), 54-57$.

Cherkashin, I., Demidova, S., Imai, S., Krishna, K. (2008): The inside scoop: Acceptance and rejection at the Journal of International Economics, Queen's Economics Department Working Paper, No. II66, Kingston.

Chubin, D.E., Hackett, E.J. (1990): Peerless Science: Peer Review And U.S. Science Policy, New York: State University of New York Press.

Cohen, P. (2007): In economics departments, A growing will to debate fundamental assumptions, in: The New York Times, July II, 2007.

Cohen, P. (2009): Ivory Tower unswayed by crashing economy, in: The New York Times, March 4, 2009.

D'Orlando, F. (2010): Electronic resources and heterodox economists, in: Cambridge Journal of Economics, forthcoming.

Dahlem-Report (2009): The financial crisis and the systemic failure of academic economics, mimeo, University of Kiel, February 2009.

European Science Foundation [ESF] (2006): Conference Report. Peer review. Its present and future state, Prague, October I2 - I3, 2006, Strasbourg: ESF, March 2007.

Frey, B. (2002): Publishing as prostitution? Choosing between one's own ideas and academic failure, Inst. for Empirical Research in Economics, Working Paper Series, No. II7, Zurich, publ. in: Public Choice, II6 (2003), 205-223. 
Frey, B. (2009): Economists in the PITS?, CREMA - Center for Research in Economics, Management and the Arts, Zurich, mimeo.

Frey, B., Osterloh, M. (2006): Evaluations: Hidden costs, questionable benefits, and superior alternatives, University of Zurich Working Paper Series, No. 302, Zurich.

Frey, B., Rost, K. (2008): Do rankings reflect research quality?, CESifo Working Paper, No. 2443, Munich.

Grijalva, T., Nowell, C. (2008): A guide to graduate study in economics: Ranking economics departments by fields of expertise, in: Southern Economic Journal, 74(4), 971 - 996.

Hayes, C. (2007): Hip heterodoxy, in: The Nation, June II, 2007.

International Mathematical Union (IMU), International Council of Industrial and Applied Mathematics (ICIAM), Institute of Mathematical Statistics (IMS) (2008): Joint Committee on Quantitative Assessment of Research, Citation Statistics, Report, June 2008, URL: http://www.mathunion.org/fileadmin/IMU/Report/CitationStatistics.pdf.

Journals under threat (2008): A joint response from history of science, technology and medicine editors, Joint Editorial of about 35 journals, first published July I6, 2008.

Kaletsky, A. (2009a): Economists are the forgotten guilty men, in: The Times, TIMESONLINE, February 5, 2009.

Katzner, D. (2OIO): To the Edge of Camelot: A History of the Economics Department at the University of Massachussetts at Amherst, book manuscript, unpubl., available through the UMass Amhorst website.

Kaletsky, A. (2009b): Now is the time for a revolution in economic thought, in: The Times, TIMESONLINE, February 9, 2009.

Klein, N. (2007): The Shock Doctrine: The Rise of Disaster Capitalism, New York: Henry Holt $\&$ Co.

La défense des revues de sciences humaines et sociales (2009), URL: www.shesp.lautre.net/spip. php?article46.

Lee, F.S. (2009): A History of Heterodox Economics, London: Routledge.

Lee, F.S., Elsner, W. (2008): Publishing, ranking, and the future of heterodox economics, in: $O n$ the Horizon, Special Issue, I6(4), I76 - I84.

Lettera aperta sulla valutazione della ricerca nelle discipline economiche (2009), URL: www. letteraapertavalutazionericerca.it.

Lutz, M.A. (2008): The `Dismal Science - Still? Economics and human flourishing, in: Review of Political Economy, 20(2), 163 - 180.

Meltzer, A.H. (2009): Reflections on the Financial Crisis, in: Cato Journal, 29(I), 25-30.

Oswald, A. (2006): Prestige labels, Royal Economic Society, Newsletter, No. I35.

Raveaud, G. (2008): Pluralism in economics teaching: Why and how, mimeo, Article for a volume of What Next, Dag Hammarskjöld Foundation, URL: www.dhf.uu.se/whatnext/ WN_papers_public.html. 
Seidl, C., Schmidt, U., Groesche, P. (2005): The performance of peer review and a beauty contest of referee processes of economics journals, in: Estudios De Economia Aplicada, 23(3), $505-55 \mathrm{I}$.

Taylor, J.B. (2009): Getting OffTrack: How Government Actions and Interventions Caused, Prolonged, and Worsened the Financial Crisis, Stanford: Hoover Institution Press.

Tol, R.S. (2007): The Matthew Effect defined and tested for the roo most prolific economists, Research Unit `Sustainability and Global Change`, Working Papers, FNU-I43, Hamburg.

Warsh, D. (2008): A brave army of heretics, URL: www.economicprincipals.com.

\section{Protektionismus: Die Grenzen der Staatsintervention in den I930er Jahren}

Protectionism: The limits of state intervention in the I930s

Jürgen Nordmann*

»Manchmal bleibt dem Historiker nur die ernüchternde Einsicht, dass es, auch nach der Prüfung aller hypothetischen Möglichkeiten, für schwierige Situationen überhaupt keine gute, sondern nur eine vielfach belastete Lösung gibt." (Wehler 2003: 215)

Die erste Weltwirtschaftskrise und ihre Bewältigung gelten als Präzedenzfall für die Modelle der Krisenbekämpfung nach dem Crash 2008. Die Versuche von I930 bis 1939, der Krise Herr zu werden, schätzen insbesondere Liberale als verfehlt ein, weil die Rezession nicht schnell überwunden werden konnte und eine Rückkehr zum alten Liberalismus in den Industriestaaten nicht gelang. Das drückt sich in der negativen Bewertung der wohl prägenden wirtschaftspolitischen Linie der I930er Jahre aus: dem nationalen Protektionismus. In der Forschung dominierte lange unwidersprochen die Auffassung, dass der Protektionismus die Krise verschärft habe, mithin die Kosten für die Hilfe der eigenen Industrie den Nachbarn auferlegt habe, somit den Imperialismus gefördert und den Weg in den zweiten Weltkrieg forciert habe (u.a. Deppe 2003: 377). Aber die Bilanz der wirtschaftspolitischen Maßnahmen kann inzwischen als gemischt angesehen werden, weil auch Stimmen wieder Gehör finden, die die stabilisierende Wirkung des Protektionismus in den I930er Jahren würdigen (Mazower 2000: I88). Denn langfristig waren es der New Deal respektive der eng verwandte Keynesianismus, die letztlich die Krise überwanden. Die positive Seite dieser Konzepte wird

* Johannes-Kepler-Universität Linz.

(C) INTERVENTION 7 (I), 20I0, 42-50 